\title{
Benchmarking the Egyptian Shopping Tourism Sector against International Best Practices in Dubai, UAE
}

\author{
Dr. EmadEddin AbuEIEnain \\ Dr. Saber Yahia
}

\begin{abstract}
Shopping tourism has become one of the main economic motivators for tourism development in several destinations. "Shopping means entertainment and experience. Regardless of trip purpose -business, family or vacation-shopping is woven into the human interactions of the visit." It means exploring and discovering and could be about the planned or temporary consumption. Shopping became gradually more significant element of the tourism "value chain". Shopping has improved into a contributing factor determining tourism destination selection, a vital element of the total tourist knowledge and, sometimes, the major tourism incentive. Destinations have consequently an enormous chance to influence this innovative "market trend" by increasing realistic and exclusive shopping experiences that enhance value to their tourist deal while strengthening, and even, outlining their tourism brand and planning. This research suggests that there are increasing numbers of tourists who are travelling to Dubai with the aim of shopping, not only because they are encouraged by a mixture of first-class shopping, reasonable costs, trustworthy deals, Duty-free and a variation of rate or goods related aspects, but the charm of the destination certainly creates decision when selecting a destination. This study provides an outline of the significance and up-to-date types of shopping tourism, principally in the emerging market of Dubai, offering recommendations to support Egypt as a central tourist destination to stimulate the inbound shopping tourism. This research first examines relevant literature on possibility to develop this tourism type in Egypt and make it one of the tourist attractions by comparing it to Dubai, UAE as a shopping destination. The study explores the objectives, and factors affecting the progress of that type in Egypt and the improvements made in Dubai. The research then investigates potentialities of developing that type in Egypt and its impacts on improving the tourist experience in Egypt and increasing the tourist flow into Egypt. Results indicated that shopping tourism could face several obstacles in practical performance, but it could be very helpful in supporting the tourism industry in Egypt especially at the time of deterioration. However, shopping tourism can also offer incentives to the tourism employees who have almost lost their jobs and may change their career. Benefits are not only confined to this, but also extended to cover enhancing existing tourism types and introducing new ones as well as enhancing the tourist numbers and their average expenditure. The Research provides recommendations for actions that could encourage more tourists to visit Egypt as a shopping destination.
\end{abstract}

Keywords: shopping, Dubai, purchasing, goods, products.

\section{Introduction}

\section{Definition of Shopping Tourism}

Shopping is an action in which a consumer looks through the obtainable products or services offered by one or more stores intending to buy a proper choice of them. In some contexts it may be considered a leisure activity as well as an economic one. Even though, the correlation between tourism and shopping must be of essential care. (UNWTO 2014)

Shopping as a tourism stimulus has turned out to be a motivation to leisure industry and is currently a major tourist type. Tourists are gradually selecting shopping as a method to practice native culture activities concluded through an involvement with domestic goods and native craftsmen. Various destinations offer distinct tourist shopping types for tourists to buy their products.

Shopping tourism has appeared as a mounting element of the travel experience, either as a principal incentive or as one of the main deeds commenced by tourists at destinations. It is a fashionable type of tourism promoted by individuals for 
whom buying products away of their typical atmosphere is a decisive factor when they take the decision to travel. (UNWTO 2014(UNWTO))

Women are usually more concerned and more interested in shopping, encouraged partially by leisure and partially by need. Alternatively, by assigning particular period for shopping when traveling, women tend to allocate a high social value to shopping as a leisure activity. (MICHALKÓ, G. and RÁTZ, T. 2006)

\section{Importance of Shopping Tourism}

Shopping has changed from being a side tourist's activity to a very significant motivation and is a main aspect while selecting a destination over another. This phenomenon is one of the main economic aspects in tourism development in the upcoming decades, owing to its great added value, capability to create jobs, tourism activity, return of main infrastructural investments and creativity.

Tourism types are varying with times, as tourist currently not only travels for leisure or business but also for shopping. The overall perception of a consumer has improved over the years from reductions to trademark existence and diversity presented.( Mehta, S. and others2014)

According to the World Tourism Organization, "shopping tourism has experienced an increase in the number of international tourists and visitors travelling to indulge in more retail activities. Taking advantages of this growth, countries are now focusing on promoting themselves as a shopping tourism destination and implementing the tools needed to meet the growing needs of these affluent shopping tourists."(Westwood, S. (2006)

When tourists are buying goods for diverse motives, they may support a destination to improve a positive mental picture in the awareness of tourists or their friends and relatives by sharing experiences through photos and videos. (Kim, S., \& Littrell, M. (2001)

In Malaysia shopping represents the second largest tourism expenditure after accommodation and the significance of shopping for global tourists has been acknowledged since over twenty years. The government introduced the 'Malaysia Mega Sales Carnival' that takes place for about three months every year and stimulates the country's fashion industry and culture. Moreover, in New York the major activity among all visitors is shopping. Barcelona, which is representing shopping tourism nowadays, is hosting a five kilometer long Shopping Street - the Barcelona Shopping Line- found in the same regions as the greatest tourism attractions of the city. Additionally, Vienna, which is one of the top international shopping cities, attracts high-class visitors from Russia, Asia and the Arab countries and offers special shopping perceptions.

\section{Shopping Tourism Facts}

- $\quad$ Of the 5 most common things travelers are willing to spend more on as an indulgence, shopping tourism ranked 4th overall with $35 \%$ of the total tourist activity count.

- Shopping tourism is intimately related to city travel.

- $\quad 58 \%$ of business travelers add a day or even a weekend to their business trip.

- Shopping tourism is an important factor for travelers when choosing their trip and destination.

- Small and local shopping experiences are much more attractive for travelers than the big global brands.

- Shopping tourism is the primary focus of leading urban destinations worldwide, as it multiplies the impact of tourism on the economy and employment.

- $\quad$ Non-EU tourists generate the most income in shopping tourism. Spending on shopping is four times higher than for EU residents, and seven times the national average. Tourists from Asian countries have significantly higher average sales receipt amounts.

- $\quad$ Saudi Arabia and the United Arab Emirates have purchase receipts higher than the average.

- Growth forecasts for international tourism are exceptional. The World Tourism Organization estimates that in 2030 , the number of international tourists will reach 1,800 million (2014: 1,133 million).

- $\quad$ Asian countries lead in terms of source market growth: forecasts are for $5 \%$ annually, and an average of 17 million international tourists every year.

Ease of accessibility, transport and safety are important factors for shopping tourists when choosing destinations. 
The main elements which attract tourists to luxury destinations are culture, shopping, and gastronomy. Entertainment options, cultural events, and other activities are factors which attract and create loyalty with tourists who shop. (HedricWong, Y. and Choong, D. 2016)

\section{Sopping Tourism in Dubai}

Dubai has become one of the most popular shopping destinations all over the World competing super cities like Paris, London, New York, and Beijing. Over the last decade Dubai has promoted itself as a city of shopping malls, luxurious lifestyle destination and land of opportunities for stores from all over the world. In addition to a long list of luxury brands and a wide diversity of merchandizing choices, Dubai's shopping centers have also been globally recognized for their unique facilities, such as the one-of-a-kind indoor ski slope at the Mall of the Emirates, and the majestic view of the iconic Burj Khalifa tower at the Dubai Mall, one of the largest shopping in the world.

It is very obvious that if the individuals do not enjoy being in a mall, and then they shop rapidly and return back quickly. Therefore, one way to keep the customers at the mall longer is to make the shopping experience more enjoyable. Existence of different kinds of specialty entertainment amenities like snooker, bowling, movie theatre etc. has a vital significance for the attraction of tourists. They want things like sport centers, dance clubs, restaurants playground for kids and cafe. (Kaur, A. 2013)

One of the main motives of tourists visiting Dubai is to shop at various malls mainly in the Dubai's old market mentioned as Souk market, Gold Souk being one of the most famous among them. Significant amount of revenue is contributed to retail industry through tourists. Dubai has more than 70 shopping centers. It is regarded as the shopping capital of Middle East region.( Mehta, S. and others2014) 2014

Dubai shopping festival (DSF) is organized in January month every year, it has played a very important role in enhancing the fame of Dubai as a exceptional shopping and tourist destination. The festival was inaugurated in 1996 as the innovation of His Highness Sheikh Mohammed bin Rashid Al Maktoum, Vice-President and Prime Minister of UAE and Ruler of Dubai, and was founded on his vision to convert Dubai into a modern city, and a major trading and shopping hub of the region.

Global Village Dubai opened in 1997 as a leading family entertainment and cultural attraction in the region that offers a exclusive shopping experience with its 30 pavilions, each representing a different country. Global Village offers several dining, shopping, and entertainment options for visitors to choose from.

The common themes of distinctiveness and multiplicity of the goods sold and the presentation of the village and it surrounds to tourists, both of which help to distinguish the experience from mainstream urban shopping experiences, were identified as key success factors.( Murphy, L. and others2008)

\section{Shopping Tourism in Egypt}

The Egyptian Tourism Sector has seen various improvements such as marketing, ICT infrastructure and human resources, in line with the ministry's efforts to promote Egypt as a worldwide tourism destination. New niches areas like shopping tourism have evolved. (OECD2010)

Egypt has a wide variety of shops, from the popular bazaars such as the thousands of stores scattered across the country that hold everything from jewelry to clothing to food. The Souks, or the local markets, and the larger bazaars are the most amazing attractions of Egypt. The most famous and widely known bazaar in Egypt is the Khan El Khalili Market in Al Hussein District in Cairo. This bazaar is about 500 years old and, although at first it appears to be just for tourist attraction, holds gift and souvenirs as well as wonderful jewelry, glass, copper, and brass-ware where the tourists can get wonderful prices from the artisans. In the contrary of the traditional Souks, many larger cities in Egypt like Cairo and Alexandria have some large malls and shopping centers like City Stars, Nile Hilton Mall, Nile Mall, and Geneina Mall in Cairo, San Stefano Mall, Zahran Mall, and Grand Palaza Mall in Alexandria where globally recognized brand names can be found in a much less hectic atmosphere. 


\section{Obstacles and Opportunities of Shopping Tourism in Egypt}

There is a sequence of prevailing issues, as acknowledged in a report by the Organization for Economic Cooperation and Development, which oblige the consideration of officials at all levels if the tourism industry is to reach its full prospective in backing social and economic growth worldwide.

The greatest obstacles to the sustained development of the shopping tourism sector are those that touch the tourism industry as a whole. There is, nevertheless, a sequence of more particular parts that destinations should study as vital to the sustained development of the shopping tourism sector.

To guarantee the best possible outcome for all stakeholders in a shopping tourism destination (visitors, local residents, tourism operators \& suppliers, local government \& tourism organizations, regional tourism organizations, State tourism industry councils and national tourism organizations), continuous, controlled and significant discourse is crucial between all of these. This involves the establishing of public-private partnerships. The following table shows some of the areas to consider when establishing such partnerships:

\begin{tabular}{|l|l|}
\hline Accessibility & Good air connectivity, efficient tourist visa regime \\
\hline Infrastructure & $\begin{array}{l}\text { Dependable and efficient local transport links, parking facilities, energy supplies } \\
\text { to } \\
\text { businesses }\end{array}$ \\
\hline Safety & $\begin{array}{l}\text { Political and social stability, security against terrorist attack, violence and petty } \\
\text { crime }\end{array}$ \\
\hline Cleanliness, attractive location & Provision and maintenance of shopping areas, street furniture etc \\
\hline Marketing and destination promotion & Effective research, planning and execution of marketing programs \\
\hline Connect the tourism value chain & $\begin{array}{l}\text { Bring other tourism partners to the table (accommodation, transport, visitor } \\
\text { attractions...) }\end{array}$ \\
\hline Research and development & $\begin{array}{l}\text { Carry out research on visitor profiles, consumer trends, market behavior; engage } \\
\text { with all } \\
\text { stakeholders and share information }\end{array}$ \\
\hline Regulation & $\begin{array}{l}\text { Maintain an open and flexible approach to business trading hours and taxation; } \\
\text { ensure } \\
\text { rigorous implementation of trading standards legislation }\end{array}$ \\
\hline Training and education & $\begin{array}{l}\text { Join in training and education programmes to produce a well-trained, motivated } \\
\text { and } \\
\text { innovative workforce }\end{array}$ \\
\hline
\end{tabular}

Source: World Tourism Organization (UNWTO), Global Report on Shopping Tourism, Madrid, Spain, May 2014.

\section{Findings}

Based on the wide analyses and negotiations of connected literatures, this study suggests that shopping tourism is anticipated to be the most vital tourism type in the future.

1. The study of shopping tourism is still inadequate and in an investigative stage.

2. For tourists, Shopping is considered not only a process of buying products, but also a home of amusement and leisure.

3. The development of Shopping Districts and places can inspire tourists to visit and extend their stay in a destination.

4. Shopping tourism has been embraced by Dubai Government as an essential aspect in a program of economic diversifications.

5. Generally, shopping tourism and all tourism types face a lot of obstacles in Egypt especially safety and security as they are the most important tasks to the incoming tourism to Egypt.

6. Dubai has an remarkable group of international brands and retail outlets competing those of any other shopping city in the world which gives the Emirate a unique advantage as the best shopping destination in the Arab World.

7. Despite, in Egypt, political events have caused worries and pressures which seem likely to further depress tourists and investors. 
8. Additional obstacles of shopping tourism in Egypt relate to humble accessibility and inadequate promotion.

9. In Egypt, Promotion and sales investment in shopping tourism are currently inadequate, and need for a great change.

\section{Recommendations}

1. To promote shopping Tourism in Egypt, There is a need for planning its international shopping brand which will stick in the minds of potential tourists.

2. The brand should create Egypt's bargain, its characteristics, and distinguishing values as a first step in establishing an ambitious and professional promotion process.

3. Egypt should also promote shopping tourism in the country and overseas through all tourism Egypt's offices as well as via various online marketing platforms including websites and social media that reach out to a worldwide audience.

4. Tourism missions, dialogues and meetings at national and international levels encompass the promotion of shopping tourism in Egypt.

5. The tourism development strategy of Egypt have to include shopping tourism as a key element to achieve the sustainable tourism development in Egypt.

6. Organizing Events like shopping festival is a very effective tool to gain a greater impact in order to promote shopping tourism in Egypt.

7. the establishment of public-private partnerships of all stakeholders in a tourism destination in the following fields: accessibility, infrastructure, safety, cleanliness and attractive location of shopping areas, marketing and promotion, tourism value chain, research, regulation, and training and education for the employees in the tourism industry.

8. Competitive pricing has been used as a key driver to attract tourists and increase tourist expenditure on shopping.

9. The exemption of import duties results in tax-exempted products, making them more attractive for tourists.

\section{References}

[1] Hedric- Wong, Y. and Choong, D., Global Destination Cities Index, Mastercard Worldwide, 2016

[2] http://flashydubai.com/dubai-has-become-the-most-popular-shopping-tourism-destination/

[3] http://itwabudhabi.com/shopping-tourism/index.html

[4] http://itwabudhabi.com/shopping-tourism/index.html

[5] http://media.unwto.org/press-release/2016-01-25/shopping-tourism-key-destinationmarketinghttp://media.unwto.org/press-release/2014-05-22/unwto-launches-global-report-shopping-tourism

[6] http://theshopping-tourism.es/?lang=en

[7] http://theshopping-tourism.es/wp-content/uploads/2015/12/EY-Shopping-Tourism-report.pdf

[8] http://theshopping-tourism.es/wp-content/uploads/2015/12/EY-Shopping-Tourism-report.pdf

[9] http://www.compass-cbs.com/shopping-tourism-course-success

[10] http://www.emirates247.com/business/dubai-shopping-festival-32-day-boost-for-economy-and-tourism-201601-23-1.618353

[11] http://www.guide2dubai.com/visiting/festivals/global-village

[12] http://www.slideshare.net/roopeshv149/attraction-shopping-entertainment-components-of-tourism

[13] https://carolyndanilowicz.wordpress.com/2013/04/06/shopping-in-egypt/

[14] https://prezi.com/bqnzsc-4zwj0/shopping-tourism/ 
[15] Kaur, A., Shopping Malls: The Changing Face Of Indian Retailing -An Empirical Study Of Cities Of Ludhiana And Chandigarh, International Journal of Business and Management Invention ISSN (Online): 2319 - 8028, ISSN (Print): 2319 - 801X www.ijbmi.org Volume 2 Issue 5 || May. 2013|| PP.30-36

[16] Kim, S., \& Littrell, M. (2001). Souvenir buying intentions for self-versus others. Annals of Tourism Research, 28(3), 638-357.

[17] Mehta, S. and others, Impact of Tourism on Retail Shopping in Dubai, International Journal of Trade, Economics and Finance, Vol. 5, No. 6, December 2014

[18] Mehta, S. and others, Impact of Tourism on Retail Shopping in Dubai, International Journal of Trade, Economics and Finance, Vol. 5, No. 6, December 2014

[19] MICHALKÓ, G. and RÁTZ, T., Typically Female Features in Hungarian Shopping Tourism, Migracijske i etničke teme, Vol 22, No 1-2, 2006, pp 79-93.

[20] Murphy, L. and others, Tourist Shopping Villages: Challenges and Issues in Developing Regional Tourism, Cauthe 2008 - 18th Cauthe Conference, hosted by Griffith University, was held at the Gold Coast International Hotel, Gold Coast, Australia, 11 - 14 February 2008.

[21] OECD Tourism Trends and Policies 2010, www.sourceoecd.org/industrytrade/9789264077416.

[22] Westwood, S. (2006). Shopping in sanitised and un-sanitised spaces: Adding value to tourist experiences. Journal of Retail and Leisure Property, 5(4), 281-291.

[23] World Tourism Organization (UNWTO), Global Report on Shopping Tourism, Madrid, Spain, May 2014. 